\title{
SEX AS AN EXPRESSION OF HOSPITALITY- THEOLOGICAL INVESTIGATION AMONGST SOME AFRICANS
}

\author{
Author: \\ ME Baloyi ${ }^{1}$

\section{Affiliation: \\ ${ }^{1}$ Department of Philosophy, Practical and Systematic Theology University of South Africa}

\section{Correspondence to:} Baloyi Magezi Elijah

\section{Postal Address:}

Office 8-75 TvW Building, Box 392, Unisa, 0003

Email:

baloye@unisa.ac.za

Dates:

31 Oct 2016

\section{How to cite this article:} Baloyi M. E., 2016. "Sex as an expression of hospitalitytheological investigation amongst some africans". KOERS - Bulletin for Christian Scholarship, 81(2). Available at: http://dx.doi.org/10.19108/ koers.81.2.2248

\section{Copyright:}

(c) 2016. The Author(s).

Published under the Creative Commons Atribution License.
Besides the fact that sexual relationships have been understood and misunderstood in different ways, the possibility of sexual abuse remains a big issue amongst African South Africans. It has been sexual relationships, amongst other factors, that have been widely used by one gender to dominate the other. Sometimes this happens because women, because of their defencelessness, are perceived to enjoy the kind of sexual abuse they are subjected to. It is from this kind of attitude that some people, particularly men, come to the conclusion that sexual intercourse is another form of hospitality that can be offered to women. This kind of thinking has been fuelled by the traditional rejection of singlehood or widowhood and other related situations that women find themselves in. It is for this reason that polygamy, levirate marriage and cohabitation have crept into the minds of some men. This paper will attempt to unveil how thinking of sexual intercourse as extending a form of hospitality has encouraged the domination and abuse of women in the African context. The study will also unveil how the gift of sex has been misunderstood and misinterpreted in order to subject women to sexual violence and harassment.

Keywords: Sexual relationships, sexual abuse, gender domination, sex as expression of hospitality, polygamy, levirate marriage.

Afgesien van die feit dat seksuele verhoudinge op verskillende wyses verstaan en misverstaan is, bly die moontlikheid van seksuele misbruik ' $n$ groot probleem onder Suid-Afrikaanse Afrikane. Dit was nog altyd seksuele verhoudinge, sowel as ander faktore, wat wyd deur een geslag gebruik is om die ander geslag te domineer. Soms gebeur dit omdat gedink word dat vroue, as gevolg van hulle weerloosheid, die soort seksuele misbruik waaraan hulle blootgestel word geniet. Voortvloeiend hieruit ontstaan die houding dat sommige mense, veral mans, tot die gevolgtrekking kom dat seksuele gemeenskap ' $n$ vorm van gasvryheid is wat vroue behoort te geniet. Hierdie soort denke word aangehelp deur die tradisionele verwerping van enkellopende vroue en weduwees en ander soortgelyke situasies waarin vroue hulleself bevind. Dit is om hierdie rede dat poligamie, swaershuwelike en saambly sommige mans se denke insluip. Hierdie artikel sal poog om aan te toon hoe ' $n$ denkbeeld van seksuele omgang as ' $n$ vorm van gasvryheid die dominasie en mishandeling van vroue in die Afrika-konteks versterk is. Die studie sal ook aantoon hoe die "geskenk" van seksuele omgang vroue meer blootstel aan seksuele geweld en mishandeling.

Sleutelwoorde: Seksuele verhoudinge, seksuele misbruik, geslagsdominasie, seks as uitdrukking van gasvryheid, poligamie, swaershuwelike 


\section{INTRODUCTION}

Let me introduce this study by quoting an address given by the MEC for Sports, Recreation and Culture, Pemmy Majodina, as she said: "Leave your Tupperware behind. I am sure you know Eastern Cape women are very beautiful. You must leave your partners behind. Two by two is not allowed" (Nteyi, 2014:3). This was one of the opening speeches for the 2014 Arts and Culture Week in Grahamstown, near Port Elizabeth. It is unfortunate that these irresponsible statements were not made by an ordinary person, but by a government leader and one of the leading female stalwarts of liberation. Besides the reduction of the image of women to a mundane object like Tupperware, the others from the Eastern Cape are reduced to being instruments of hospitality, available to upcoming visitors to the province. The motivation of this kind of thinking is that some African or black women are expected to show hospitality to strangers who will be coming from different parts of the country. It is not clear whether the Eastern Cape women are for or against this view, but if they are for it, then one doubts whether all the females in that province would want to regard themselves as people to stand up for their human rights. It should be understood that women's rights are in the very first instance quite simply human rights, and what is reflected in this public utterance is a pathology which needs to be arrested and destroyed if we are still serious about winning the battle of gender imbalances in this country. After hearing this statement the author was quickly reminded of a statement by John Mbiti (1990:143) who indicated that there were (still) areas where sex was used as an expression of hospitality amongst Africans.

The author intends to introduce the engagement of this article by quoting one of the well-known verses from Hebrews 13:2 which says: "Do not neglect to show hospitality to strangers, for by doing that some have entertained angels without knowing it." The Greek word for hospitality is "philoxenia" meaning "love of the stranger" and has as its direct opposite "xenophobia" which is "hatred of the stranger" (Vine, 1981:235). In Matthew 25:31 Jesus promised to be with those offering hospitality, which could in that context be understood as solidarity with strangers (Lloyd-Siddle, 2006:142). The practice of hospitality in general has been a very common characteristic for African people. An African without hospitality cannot be imagined or identified in African culture. It is because of this hospitality that Africa as a continent became one of the most exploited continents by colonisers, who ended up taking its resources. Unfortunately, this excessive belief in hospitality has gone too far, creating the thinking in some African people that there should even be hospitality in sexual matters. Kyomo and Selvan (2004:85) argue that a male visitor should be offered a daughter or sister for the night by the host. This could also be done with a deserted wife in a form of levirate marriage. African women are identified by their hospitality, hence Oduyoye (2001:91) quoted Mbondo by saying: "Women's tenderness and hospitality, security at home would be impossible for the other sex is not committed to such things. Women's role in the home as those who make 'life more poetic', but admits that paradoxically, they are also the ones who are the object of violence and intimidation."
The revival of the 16 days of Gender Activism is already being initiated with political and community leaders starting to publicly speak about it. It is said that despite celebrating 16 days of gender activism, we are also celebrating 16 years of this activity in South Africa, which is a good reminder to all of us about the gender equality that we are seeking to establish as a nation. It is within this context that this article intends to unveil sex hospitality as a traditional weapon not only against the subject, but to oppress, abuse and violate women's rights in the South African context in general. The traditional portrayal of sex as an act of hospitality has been alleged to be an issue amongst some African tribes. It is for this reason that women have been seen as people who should be made available to please men sexually. Some definite taboos and other traditional stereotypes are used to make this belief an acceptable one. For this reason, instead of reducing the gender-related based violence, South Africa is experiencing massive multiplication of the oppression of one gender by the other. Although there has been a growing concern about sex-related offences that are escalating in South Africa, some of the causes have gone unnoticed. There have been many structural ways in which females are subjected to subordination. One of the perceptions is that women or females should entertain or take care of people, including strangers.

\section{RELEVANCE AND METHOD OF THE STUDY}

It is undeniable that even after 22 years of democracy, women are still viewed as subordinates to men in different spheres of life, whether it be the workplace, home or public life. Sexual harassment, rape and other means of forced sexual relationships continue to top the list of offences that are committed daily in this democratic nation. The dignity, human rights and freedom of women are not only under attack, but also systematically and structurally being undermined. Any theology that attempts to ignore or turn a blind eye when females are reduced to objects is not only irrelevant, but it does not deserve to exist at all. Practical theology of liberation argues that theology must begin from human pain. The plight of women in celebrating 16 years or 16 days of activism during December cannot be relegated to the ears of the government and gender related NGOs alone, but demands the interpretation and praxis of theology. A lot of theologians have written much about being the voice of the voiceless women, but not much has been done to eliminate these violations and abuses.

\section{THE CONCEPT OF HOSPITALITY}

\subsection{Brief background}

The unconditional readiness to share, give freely and be an extension of generosity has characterized what we call African hospitality for many decades. It includes to help, to assist, to love and to carry one another's burden (Echema, 1995:35). According to Olikenyi (2001:102) it is a vital aspect of existence in Africa and it is still practices by many Africans despite the forces of external influence. Mbiti (1990:1) acknowledged that it permeates all spheres of African life. There is a sex hospitality background from the ancient near East, particularly from the 
Hebrew Bible, according to Gur-Klein (2003). The book entitled "Sex and family in the Bible and the Middle East" by Hungarian Jewish historian, Raphael Patai (1959) deals with patriarchal hospitality which went so far as to override women's chastity.

\section{According to Gur-Klein:}

The custom has been practised among tribal, nomadic and decentralized societies and has been practiced from Yemen through Central and North Arabia, North Africa and Australia and from Egypt to Afghanistan. The origin of the custom seems to be rooted in ancient times, surviving into and often tolerated by the Islamic era. Commonly, the man concerned is an outsider and not a tribesman. The outsider and/or guest would be led by a family member who thus plays the procurer. The template may vary from one community to another. In some tribes sexual hospitality concerns unmarried daughters, while in other tribes only married women will practise it.

In order to emphasize that the practice of sex hospitality is derived from ancient biblical times, Gur-Klein quoted Genesis 19 and Judges 19. The first is the story of Sodom and Gomorrah, when the men of the city in which Lot lived surrounded his house and demanded of him to release the guests who were there. They wanted to have sex with those guests but Lot refused and said: "Look, I have two daughters who have never slept with a man. Let me bring them out to you, and you can do what you like with them" (Gen.19:8). This depicts the harsh reality that females were availed to offer hospitality with regard to sexual gratification of any kind of guest. In other words, the Judaeo-Christian tradition is not innocent with regard to gender inequality, which amongst other things manifested itself through availing women as agents of sexual hospitality.

\subsection{What is sexual hospitality and how was it entrenched?}

The Longman Dictionary defines hospitality as a friendly behaviour towards visitors (Longman, 2001:691). The original Greek translation goes on to say "love of strangers" went beyond just ordinary visitors to even include strangers (Vine, 1981:235). One of the most prominent characteristics of being African is hospitality. To sum up the definition of hospitality the author refers to the act of being available and friendly to receive visitors, including strangers. Sexual hospitality was evident during the times of slavery, where slaves were always ready to offer their bodies for a trifle and towards evening one could see a string of soldiers and sailors entering the slave lodge (Van den Berghe, 1965:18). For the sake of this study, I would suggest that hospitality be understood in terms of what Gathogo (2006:1) refers to when saying that it is an extension of generosity, given freely without strings attached. The uniqueness of African hospitality is that it has less pretence and a more natural approach towards the principle of sharing the joys and sorrows of this life.

Good practice as we get to know it from the Ancient Biblical Patriarchs to Africans, has been revealed many times that hospitality was also used to subject women to male domination. In her article entitled "Without a voice, with a violated body", Masenya (2012:209) clearly confirms that hospitality was essentially demonstrated by women. She went on to argue that Judges 19 is a portrayal of the gendered act of hospitality. This is evidenced when the man was confronted with a challenge to show hospitality and make peace with the Israelite strangers, and his first option was to offer his own wife so that at least he would be at peace with strangers, at the expense of his wife (Masenya, 2012:211).

One popular Tsonga idiom says: 'Wanhwana I huku yo khomela vayeni' (Daughter is a hen to be caught for visitors) (Junod, 1990:74-75). Junod goes on to motivate this saying by indicating that when a girl or daughter marries, she leaves her village and hence she is like a hen which you must catch to entertain your guests. There can be different objective or subjective interpretations of this idiom, but the main one would refer to girls or daughters as people being made available to visitors. The role of culture and idioms cannot be under-estimated when dealing with issues of gender inequality amongst African people. These sayings have been traded from one generation to the next. They have their role in shaping the lives and identities of African people. When this saying is transmitted to the young girls the intention is to make them feel, even at a young age, that they are growing up simply to be available for men's pleasure. It was for this reason that even the raising of girls was accompanied by the stereotypes that promoted male dominance. It connects back to notion why the birth of males is always more important than females in the African context.

In order to motivate the argument of daughters and women being used for sexual hospitality there is the issue of "ku hlayisa" which literally means to "take care". In XiTsonga there is a close relationship between "ku hlayisa" and "ku teka" and these two are often used as synonyms (marrying and taking care of). In Baloyi (2015:483) it has been indicated that when the family agrees, suggests or even forces widows to marry a brother or relative of the deceased, the concept that is emphasized is that she needs to be taken care of. It should be remembered that in the African context, one form of hospitality is evidenced by taking care. This is regardless of whether or not the widow has been left with the financial means to take care of herself. Therefore this clearly indicates that there is a special "care" that a single or unmarried woman deserves, and must have. According to Baloyi (2015:483) this mode of compassion is fulfilled in sexual gratification.

This is the context from which we must understand this saying. This saying is not far from what happened in Judges 19 where the father was ready to show his hospitality by availing his own daughter to the sexual fulfilment of a stranger. Judges 19:24 reads: "Look, here is my virgin daughter, and his concubine. I will bring them out to you now, and you can use them and do to them whatever you wish. But as for this man, don't do such an outrageous thing." Although it is not the main focus of this study, it can be suspected that there was a custom of making peace with hostile strangers by sacrificing their daughters. 
Masenya (2003:107) is correct in arguing that hospitality in this context was/is basically demonstrated by women. It is for this reason that the general perception is that a single woman or widow must have someone to take care of her. Another example can be found in Genesis 19 where Lot was ready to give his daughters to strangers, which can often be misinterpreted to means that this kind of practice should be condoned. Genesis 19:8 reads: "Look, I have two daughters who have never slept with a man. Let me bring them out to you, and you can do what you like with them. But don't do anything to these men, for they have come under the protection of my roof."

Unfortunately, women are also made to strengthen, perhaps involuntarily, these kinds of thoughts. We often find women who feel incomplete without sexual relationships. One testimony of this can be read from Nyathi's (2015:2) report about an incident where disabled women in Mpumalanga are crying that men disregard them when it comes to sexual gratification. Mbuyane Jeaneth, the representative of the Masoyi Protective Workshop, an NGO dealing with disability, was quoted as saying: "We are human beings and have feelings like any other citizen. We also have wombs to carry babies like any other woman." This report avowed that disabled people have a right to demand their right to sex (Nyathi, 2015:2). Whether this right should be demanded from where or who, the report did not clarify. Unfortunately, no mention of marriage appeared in that report, only sex. If disabled women express this kind of a demand, then there must be a good to reason to understand that they regard themselves as incomplete without sexual intercourse. This stereotype speaks to the idea that single women in the African context are often suspected of a lack of feelings of intimacy (Baloyi, 2010:725), not living normal lives (Reynolds, 2008:1230) and other socially related stigmas.

According to Mbiti (1990:143), it is true that there are areas where sex is used as an expression of hospitality. It is understood to be an issue of hospitality expressed by women who need to fulfil such a desire. On the other hand, if a man visits another, the custom is for the host to give his wife, daughter or sister as a welcoming gesture towards the guest. That is why in cases where the husband is forced by circumstances to live away from his wife for a long time, it may be arranged for a friend (particularly a husband's brother) to have sexual intercourse with the "deserted" wife (Kyomo \& Selvan 2004:85).

\subsection{The misunderstandings of the role of women in the family and society}

The misunderstanding and misinterpretation of the role of the woman in sexual relationships which has been orchestrated by patriarchy, gives the wrong picture of women. That is why many women, particularly singles, are seen as people who are vulnerable and therefore desirous of succumbing to sex by men in a random manner. Their actions are usually interpreted to be an invitation to a man to have sex. Jacob Zuma was quoted as saying: "And I said to myself, I know as we grew up in the Zulu culture you don't leave a woman in that situation because if you do then she will even have you arrested and say that you are a rapist" (Waetien, 2009:2). Although the woman did not provide her own version of this statement, for the focus of this study it is important to intimate that this kind of perception about women does not only fall within generalization, but also implicates the portrayal of women as being vulnerable when it comes to the issue of sex. Without this understanding of various possible situations, it becomes very difficult to imagine women without having some sexual desires and capabilities. The entrenchment of this thinking informed the author to see the correctness in the work of Masenya (2003:102) when she argued:

It becomes understandable that male-oriented societies have a tendency to confuse or even equate sexual activity with sexual violence. It is even more disturbing for religious communities, that some sections of the sacred scriptures are interpreted to support sexual violence against women and children. Women's sexuality is often defined and controlled by men both in the churches and in the households. Female bodies become sacrifices at the altars of male power and pleasure.

It is very disturbing that while the tacit support of gender disparities is not just against the constitution of this country (which emphasizes the promotion of gender equality), it it also dehumanizes women while violating their intrinsic human rights. That is the danger of trying to interpret women's rights in isolation from basic human rights. Such a view is partly derviced from people like Napoleon who said: "The male is assumed to possess a sort of generic human identity, whereas the female has more of sexual identity" (Groothuis, 1994:33). The author is in full agreement with Gur-Klein (2003) who emphasizes that such customs as are discussed here are inherently-male oriented as they concern a situation of patriarchal hospitality in which female chastity is waived for the pleasure of a male guest. The few tales that we read about with regard to this practice portray only women on the receiving end, meanwhile men are just guests to be shown hospitality. One could readily ask when men would condescend to offer themselves for this kind of hospitality which in essence is a total reduction of females into being mere agents of hospitality or sexual objects.

\subsection{The role of the media in portraying women as sexual hospitality givers}

There have been many complaints as to how our media handles pornography, which in one way or another helps in promoting the agenda of women as mere sexual objects. Cloete's (2012) article entitled "Youth culture, media and sexuality" reveals much of the influence of the media on youth about sexrelated matters. Cloete argues that the $93.3 \%$ growth in the accessibility of the internet between 2000 and 2008 is an indication of the exposure of the younger generation to issues related to pornography and other negative material. South Africa does not have laws to prevent children from being exposed to pornography at a very young age. One family therapist was quoted by Cloete (2012:08) as saying: "In my practice I have seen numerous teens from as young as 11 who become involved in very disturbing sexual situations, for example teens photographing each other having sexual intercourse, orgies, having oral sex, etc. and selling it as 
pornography on the internet."

Elisabeth Le Roux (2009) in her article entitled "Pornography: human right or human rights violation?" argued that though the Commission on Gender had made a lot of complaints to the government on the regulation of TV programmes which advertise women's bodies as an instigation to commit sexual deeds, it seems that complaints have fallen on deaf ears as some TV Channels continue to show pornography even during hours when children are presumably still awake. The author's articulation is that this has to do with money because the TV channels are perhaps giving more money to the government to the extent that the voice of government is compromised. Mpumelelo (2005:8) also added that the advertisements that portray women as sexual objects are seen on billboards everywhere. Children growing up facing these challenges are therefore likely to internalize what they see or hear as part of their lives and inevitable outcome would be adopting such practices as normal and desirable.

\subsection{What about HIV/AIDS and related diseases?}

Although it has been proven by medical practitioners that sexual intercourse is not the only path through which people can contract HIV/AIDS, it should always be remembered that a large number of infections occur through unfaithfulness, meaning having unsafe sex with multiple sex partners. Therefore, if women are available to offer hospitality in a sexual way, their vulnerability to be affected by the virus becomes a huge risk. Besides women being infected, the possibility is that they will pass the disease on to the next person they host. It can also be the other way round, that the hosted stranger infects the innocent woman who offers this hospitality. For the author, sex hospitality is another form of prostitution or sex work. Sex workers in many countries have been the most vulnerable to being infected with HIV/AIDS. It has been alleged recently that the majority of sex workers in Johannesburg are HIV positive, meaning they are likely to infect as many visitors and strangers as possible (Child, 2015:10).

\section{THE WAY FORWARD}

There is relevance in asking whether the biblical passages in which the evidence of sacrificing females for the sake of showing hospitality or making peace can justify the practice (see comments on Gen.19 and Judges 19 in the background). No one can deny that the role of the understanding and interpretation of these verses in availing women for sexual gratification for strangers is an argument that holds water. But the fact of the matter is that these verses are an indication of how the earlier biblical people, particularly patriarchs, subjected women to oppression and abuse. The continuation of such practices when Christianity was brought into Africa played a significant role in entrenching the view of women as mere objects of sex. Allowing one's daughter to be sexually abused even by multiple rapists was treated as a minor transgression in the ancient Eastern customs, particularly because of the low status of the young women in society. The ancient Hebrew cultural treatment of women confirmed that according to them, women were not only the devil's doorway (Tertulian), but also a second blunder of God (Van Wyk, 1985:38).

Men think women should not be able or allowed to say no to any proposal. Women are raped and forced into sexual subordination because men never expect a hospitable person to say no. That is why even if women say no to men's proposals, they are regarded as joking and hence sex is taken from them by force. Lopez in Baloyi (2009:109) is very correct is saying that "sex can be stolen by rape, persuaded by seduction, rented through prostitution and leased by marriage". It is within this context that women's worth has been reduced so radically. The author's argument is that if women are reduced to being sex objects, just as Lopez went on to argue, then their worth is even less than that of domestic animals. In the male-dominated understanding, every woman is perceived to be craving sex and there is no expectation that she will say no when asked.

\section{COUNSELLING WOMEN}

It is of paramount importance that young and old women should be informed that they are not to blame for being made sexually vulnerable people, but that the system of patriarchy is to blame. Bringing back the worth and dignity of women also means they must have a right to the personal integrity of their mind and of their bodies (Waruta \& Kinothi, 2000:131). Women must be taught about sexual matters as much as possible while they are still very young so that they know what to expect as they grow older. Even the way young girls are raised must show them the good and bad in life. The issue of raising girls to be available for men, implying that even education is not important for them, should be relegated to the dustbin of history. Pastoral counsellors must be ready to exploit gatherings like indabas, community gatherings and other forums to educate parents on the worth of a girl child's life. Counsellors and ministers must take the projects of awareness about HIV/AIDS and other related negative effects of irresponsible sexual behaviours to the community (Chamisa \& Mjoli, 2014).

\section{MEN HAVE A ROLE TO PLAY IN LIBERATING WOMEN}

The discussions and research targeted at eliminating and arresting the situation of gender inequality in South Africa have been done in a wide range of disciplines, but they do not emphasize the involvement of men. Connell (2003:3) raises the same opinion when arguing that although equality between women and men is recognized as a principle in international law, it is evident that issues concerning gender equality are placed on the public agenda mainly by women. To add to that, Cornell indicates that men and boys are in several ways the gatekeepers for gender equality. The author's opinion is that if men had been at the forefront of this struggle, half of the battle would have already been won. Without making generalizations, the truth is that more damage on the issues of subjecting women has been inflicted by men. It is the very same men who can help to reverse the situation by becoming part of the struggle against that which they have started. Oliphant (2015:1) admits that: "Although violence against women is 'notoriously hard to measure' there is ample evidence that 
physical, sexual and psychological violence as well harmful traditional practices committed against women and girls is widespread in the country [and] often the perpetrator is a male partner or family member". James Cone's (1982:122) principle which says, "Afflict the oppressor in support of the oppressed" indicates clearly that it is unwise to deal only with recipients of injustice while the perpetrators are left to run free. This is what made the case of the woman caught in adultery (John 8:1-11) a difficult one for the Pharisees, and fortunately for them Jesus did not ask them about the man who had committed adultery with the woman. According to Baloyi (2010:1) the sin of adultery is always committed by two people of different sexes therefore the reason why the Jews brought only the woman to Jesus was a biased one. In the same vein, Meyers (2000:455) is in the same dilemma because the "partner in crime" is absent from the story. This is an indication that the patriarchal agenda pushes the women to be judged, while men are let free.

In supporting men's involvement in the liberation of women from gender inequality, Ratele and Botha (2014:1) indicate that the Medical Research Council and University of South Africa have shown that males are six to seven times more likely to die than females. The neglect of men's role in gender disparities is perhaps one of the reasons of slow change in this challenge. The author is in agreement with Porter (2014:1) who urges men to get involved in the fight for gender equality which also asks men to speak out against violence and discrimination faced by women and girls around the world.

\section{THEOLOGICAL ETHICS OF SEX AND HOSPITALITY}

Hospitality has shaped the lives of many people throughout generations. That is why Chester (2011:89) argued: "Hospitality has always been integral to the story of God's people. Abraham set the agenda when he offered three strangers water for their feet and food for their bodies. In so doing he entertained God Himself and received a fresh promise (Gen.18:1-18)." Martin (2014:1) indicates that the efforts to revive the ancient Christian practice of hospitality has been focused and drawn from the Old Testament as a model to be emulated. The writer of Hebrews (13:2) urges: "Do not neglect hospitality."

Guests are normally treated with great respect and are not expected to compensate the host (Koening, 1992:229). Despite the fact that hospitality includes a guarantee of protection for the guest, there were also risks of deception involved (Yong, 2008:111). It was for that reason that the host tried to protect his guests in Judges 19:23 saying: "The owner of the house went outside and said to them, 'No, my friends, don't be so vile. Since this man is my guest, don't do this outrageous thing."

In another incident which looks similar, Lot find himself in defence: "Lot went outside to meet them and shut the door behind him and said, 'No, my friends. Don't do this wicked thing. Look, I have two daughters who have never slept with a man. Let me bring them out to you, and you can do what you like with them. But don't do anything to these men, for they have come under the protection of my roof'" (Gen.19:6-8).
The Old Testament also teaches that hospitality normally includes water for washing the feet, food, drink, rest and care for animals. This was one of the characteristics used to find a wife. That is the gesture that Abrabam's servant waited for when looking for a wife for Isaac in Genesis 24:12-21. The prayer of the servant from Genesis 24:14 said: "May it be that when I say to a young woman, 'Please let down your jar that I may have a drink,' and she says, 'Drink, and I'll water your camels too'--let her be the one you have chosen for your servant Isaac. By this I will know that you have shown kindness to my master." After a short while Rebecca reiterated what the prayer said as an indication of the answer. Perhaps it was from this chapter that some people misshaped hospitality into another form of abuse.

God created sex and gave it for the sexual gratification of married people. The Biblical purposes of sex must be clarified and explained to help to arrest and destroy the misunderstandings about sex. Theologically, during the creation of sex there was no harmful plan to either of the two genders. Nowhere did God initiate sex with the aim of oppressing one gender by the other. It is unbiblical to use sex as a weapon of male dominance. Maciejczak (2013:1) detailed the exploration of sexual violence as a weapon of war.

The Bible indicates that, firstly, Adam and Eve were adults (man and woman) when God married and blessed them (Genesis 1:28) saying: "God blessed them and said to them, 'Be fruitful and increase in number; fill the earth and subdue it. Rule over the fish in the sea and the birds in the sky and over every living creature that moves on the ground." One of the biggest mistakes made by contemporary people is not to deal with the question of how old the couple was when they received this blessing. That is where young girls and boys start derailing and destroying their future with sexual matters which are meant for adults. Secondly, God gave sex to be expressed within the explicit domain of marriage. Although some theologians believe that a sexual union is representative of the intimacy found in the Trinity, for this study (Slick s.a.,1) argues that it is only in marriage between a husband and wife that sexual intercourse is properly expressed.

Thirdly, He also explained the purposes of sexual intercourse. Slick (s.a.,1) lists four purposes of sex which are procreation (Gen.1:28), intimacy (Song 1:13), companionship (Songs 3:1) and physical pleasure (Songs 1:2). The New Testament also builds on the foundation provided by the teachings of the Old Testament in sexual matters. Paul insists that it is men and women who are married who should give each other sexual pleasure. In partial support of this view, Hornor (2002:2) emphasizes that sex was designed to express love. Mohler (2004:1) clearly indicates that the Bible places sex and sexual activity within a larger context of holiness and faithfulness and this helps to underline that gender is part of the goodness of creation. From these few views, it becomes even clearer that sex was not created to harm or oppress any person regardless of their gender. The abuse of sex is the root cause of sex-related problems and crimes. The more sex is engaged in for the wrong reasons as well as outside of wedlock, the more troubles and complications it brings to human life. This also calls for sex education for young children. Their better understanding of the intentions of sex 
can bring more respect as well as dignity to this commonly abused gift. The churches, schools and homes should have a place and time where children are taught about sexual matters. The preachers must not shy away from telling this truth in love. Pastoral care-givers and marriage officers must emphasize sexually related issues during their premarital counselling. The truth is that although the media has a very big influence on the youth regarding sex related issues today, research shows that parents and family life still have the greatest influence on the life of children (McDowell, 2006:59-60, Cloete, 2012:09).

There is no single biblical ground for sex to be used for hospitality and hence the sex educators and Biblical preachers must play their role in separating the two issues. The connection that people make between sex and hospitality is not only unfounded, but a dangerous historically inherited heresy that aims to defile and subjugate women under male abusive dominion.

\section{CONCLUSION}

The relegation of women to being providers of sexual hospitality assists in pushing them not only further into subjection, but also to inhuman status. This is another form of making women prostitutes in the name of hospitality. Patriarchal systems and structures ensure that sex, amongst other things, is used to dominate and reduce the status of women. It is the duty of everyone to play their roles in trying to redeem the rightful status of women in society. The government has already voiced its stand through institutions like the Commission on Gender which is trying to protect the rights and dignity of women in particular. It is now the responsibility of the church and other community stakeholders to involve themselves in the fight against some of the traditional attitudes and ways of subjecting and oppressing women. Women's rights must be understood in the context of human rights and that kind of framework helps to ensure that their dignity and rights are observed and protected by men, who used to be their exploiters. From a Biblical point of view there was no single harmful or oppressive intention when sex was created and given to human beings although early patriarchal practices established the use of sex as an expression of hospitality. The correct teaching about sex at home and schools may play an important role in the fight against availing women and girls for sexual hospitality.

\section{BIBLIOGRAPHY}

Baloyi, ME. 2009. Patriarchal structures, a hindrance to women's rights. Saarbrucken, Germany: Peter Verlag.

Baloyi, ME. 2010. A re-reading of John 8:1-11 from a pastoral liberative perspective on South African women. HTS Teologiese Studies/Theological Studies 66(2), Art. \#838, 7 pages. DOI: 10.4102/hts.v66i2.838.

Baloyi, ME. 2010. Pastoral care and the agony of female singleness in the African Christian context. In die Skriflig, $44(3 \& 4), 723-742$.

Baloyi, ME. 2015. The Christian View of Levirate Marriage in a Changing South Africa. Journal of Sociology and Social Anthropology.

Chamisa, SF. \& Mjoli, TQ. 2014. HIV/AIDS Awareness Training Programmes and Risk Behaviour among Students. Journal of Human Ecology, 46(2): 157-164.

Chester, T. 2011. A meal with Jesus: Discovering grace, community and mission around the table. Wheaton, Illinois: Crossway.

Childs, K. 2015. Most Joburg sex workers have HIV, study finds. Sowetan, 14 December, p10.

Cloete, A. 2012. Youth culture, media and sexuality: What could faith communities contribute? HTS Teologiese Studies/ Theological Studies 68(2), Art. \#1118, 6 pages.http://dx.doi. org/10.4102/hts.v68i2.1118

Cornell, RW. 2003. The role of men and boys in achieving gender equality. Paper prepared for the Division for the advancement of women (DAW) in collaboration with International Labour Organisation (ILO). Brazil, EGM/Men-boys-GE/2003/BP.1. 7 October 2003.

Gathogo, JM. 2006. African Hospitality: Is it Compatible with the Ideal of Christ's Hospitality? Churchman, 120(1):39-56.

Groothuis, RM. 1994. Women caught in the conflict. The culture war between traditionalism and feminism. Grand Rapids: Baker Books

Junod, HP 1990 Vutlhari bya Vatsonga (Machangana) (Wisdom of the Tsonga-Shangaan People). Braamfontein: Sasavona Books.

Gur-Klein, T. 2003. Sexual hospitality in the Hebrew Bible. Lectio difficilior. European Electronic Journal for Feminist Exegesis. Visited on 26 November 2015 on www.lectitio.unibe. ch.

Hornor, N. 2002. God's purpose for sex and marriage. Beyond today blog posted on 26 July 2002 and accessed on 14 December 2015 on www.ucg.org.

Koenig, J. 1992. Hospitality. In D.N. Freedman (ed.), The Anchor 
Bible Dictionary, III, 1st ed., pp. 299-301, New York: Doubleday.

Kyomo, AA. \& Selvan, SG. 2004. Marriage and family in African Christianity. Nairobi: Acton Publishers.

Le Roux, E. 2009. Pornography: human right or human rights violation?, paper presented at the Joint Conference of Academic Societies and Theology, Academy of Practical Theology, Stellenbosch, 22-26 June 2009, n.p.

Longman Dictionary of Contemporary English. 2001. Third edition.

Maciejczak, J. 2013. Sexual violence as a weapon of war. E-International relations students' blog posted on o9 October 2013 and accessed on 14 December 2015 at www.e-ir.info.

Martin, L. 2014. Old Testament foundations for Christian hospitality. Verbum et Ecclesia 35(1), Art. \#752, 9 pages. http:// dx.doi. org/10.4102/ve.v35i1.752.

Masenya, M. 2003. Sacrificing female bodies at the altar of male privilege: A Bosadi Womanhood) Reading of Judges 19. Journal of Theology and Religion in Africa, 27(1):98-122.

Masenya, M. 2012. Without a voice, with a violated body: Rereading Judges 19 to challenge gender violence in sacred texts. Missionalia, 40(3):205-216.

Mbiti, JS. 1969. African Religions and Philosophy. New York: Praeger.

Meyers, C. 2000. Women in the Scripture Grand Rapids, MI.: Eerdmans.

Mohler, A. 2004. The Bible on sex: The way to happiness and holiness. Pure Intimacy blog accessed on 14 December 2015 on www.pureintimacy.org.

Mpumelelo, M. [n.d.] GE blasts misuse of women in ads City Press, 13 November, p. 8.

Nteyi, Z. 2014. Couples are not allowed in EC-MEC. Daily Sun, 2 July, p.3.

Nyathi, S. 2015. Disabled people have a right to sex-Mbuyane. Daily Sun, 25 November, page 2.

Oduyoye, MA. 2001. Introducing African Women's theology. Sheffield: Sheffield Academic Press.

Olikenyi, GI. 2001. African hospitality: A model for the communication of the Gospel in the African cultural context. Nettetal: Steyler Verlag.

Oliphant, P. 2015. South Africa falling short in gender equality standards. Mail and Guardian blog posted on 04 May 2015 and accessed on 14 December 2015 at www.mg.co.za.

Patai, R. 1959. Sex and Family in the Bible and the Middle East.
Garden City, New York: Dolphin Books, Doubleday \& Company.

Porter, J. 2014. Yes, gender equality is a men's issue. Blog posted on 26 September 2014 and accessed on 14 December 2015 on www.fastcompany.com.

Ratele, K \& Botha, M. 2014. Why men would benefit from the liberation of women. Blog posted on 24 August 2014 In The Sunday Independent and visited on 14 December at www.iol. co.za.

Reynolds, J. 2008. The single woman. London: Routledge.

Siddle, L. 2006. Celebrating our call. Ordination stories of Presbyterian Women. Louisville, Kentucky: Genève Press.

Slick, M. [n.d.]. What is the Biblical purpose of sex? Christian Apologetics and Research Ministry undated blog accessed on 14 December 2015 on www.carm.org.

Van den Berghe, P. 1965. South Africa. A study in conflict. Berkeley, Los Angeles: University of California Press.

Van Wyk, JH. 1985. Feministiese Teologie. In die Skriflig, 19(75):33-44.

Vine, WE. 1981. Vine's expository dictionary of Old and New Testament words. Grand Rapids, Michigan: Fleming H Revell.

Waetjen, T. 2009. Tradition's desire: The politics of culture in the rape trial of Jacob Zuma. Association of Concerned Africa Scholars Review (previously: Bulletin) ACAS Bulletin 84. Blog visited on 05 November 2015 on www.concernedafricascholars. org.

Yong, A. 2008. Hospitality and the Other: Pentecost, Christian practices, and the neighbour. Maryknoll: Orbis Books. 